\title{
Environment Problems of City Development in China
}

\author{
Xin Li ${ }^{1}$, Yanli Qiao ${ }^{2}$ \\ ${ }^{1}$ Tianjin Research Institute of Water Transport Engineering, MOT, Tianjin, China \\ ${ }^{2}$ ENN Intelligent Energy Co., Ltd., Langfang, China \\ Email: xin2li@yeah.net
}

Received 1 May 2015; accepted 25 July 2015; published 28 July 2015

Copyright (C) 2015 by authors and Scientific Research Publishing Inc.

This work is licensed under the Creative Commons Attribution International License (CC BY).

http://creativecommons.org/licenses/by/4.0/

(c) () Open Access

\begin{abstract}
Environmental issues in the process of rapid urbanization are critical to the sustainability of China. Compact cities, characterized by relative high density, mixed land-use and pedestrian-oriented habitation, have been proposed as one solution for sustainable urban planning. However, given the fact that Chinese cities are characterized by high population densities, the applicability of a more compact solution to expanding cities in China remains questionable. Essential to the decision-making is a deeper understanding about the relationship between urban compactness and the sustainable environment of the cities. This study is proposed for an evaluation about the urbanization and urban development in China's context from environmental perspective, especially with respect to atmospheric environment, water resources, waste pollution, and noise problems.
\end{abstract}

\section{Keywords}

Environmental Issues, Rapid Urbanization, China, Styling, Pollution

\section{Introduction}

Following the initiation of the reform and opening policy, urbanization in China increased in speed [1]. By the end of 2013, population lived in urban areas are 53.7\% of the total, a rate that rose from 26\% in 1990 [2] [3]. According to official forecast, the urbanization rate will reach $60 \%$ by 2020 [4] [5].

Urbanization, in turn, is reshaping both the physical environment and the cultural fabric [6] [7]. Take, for example, the issue of pollution [8]. Huge cities place huge demands on the environment [9]-[11], but high-density living conditions also present opportunities for improving efficiency of energy usage [12] [13].

According to World Bank indicators when evaluating the level of urbanization [14], the current level of urbanization in developed countries has reached about 80 percent [15], close to the world average of 50\% [16] [17], 
the average level of developing countries was $42 \%$, while China's level of only $36 \%$. Click here to evaluate the level of urbanization in China is in the low to mid-level transition period.

\section{Urbanization and Urban Development in China}

China is the world's largest developing country, since the reform and opening up, the rapid development of urbanization [18] [19], but China's urbanization process is not completed in the case of industrialized carried out [20]. Before the reform and opening up, industrialization and economic development is relatively backward [21], China's urbanization development stage is almost at a standstill [22]. China's urbanization rate increased from 28 percent to 45 percent only 15 years, and to increase by $1 \%$ per year rate of increase in 2035 will reach about 75\%. China's urbanization process is much faster than the developed countries in Europe and America [23]. In this regard theorists and politicians have given great attention (Figure 1).

Regional imbalances between urban development in China, the overall presentation "ladder" shape [24]. China is currently the main urban development in large cities, small towns development is highly uneven [25], most of the small city on the structure and function but also meet the requirements, pollution, traffic planning unreasonable; although cities can provide more resources and effectiveness, but development of big cities, unreasonable structure increasingly prominent contradiction city needs to provide resources and people's deterioration.

The rapid increase in the number of cities, on the other hand, there were many large cities, large cities, and many cities in the contiguous spread from urban agglomerations, belt. This is the main feature of Chinese urban spatial structure [26]. A large piece of residential areas, industrial parks, development zones in the city and other cities New Rising edge. The new industrial space, commercial ecological zones, new living space have emerged, but also spawned the formation of rapid transit network. New newly formed space is bound to expand in the open; some with concentric expansion, there are axial extension, more multi-core expansion, affecting the entire city morphology. China is in the late stages of industrialization and urbanization accelerated development, construction and development of a large number of industrial parks and development zones, making the high consumption of resources and energy [27], the overall deterioration of the environment has not been fundamentally reversed the trend, the development of unbalanced, uncoordinated and not continuing problem is more prominent.

\section{Environmental Issues of Urban Development Environment in China}

Large scale development of China's urbanization is uneven regional development (Figure 2). Many problems brought about the development process of urbanization have emerged [21]. Urbanization process, a lot of the rural population into the cities, and the influx of urban population should enjoy the benefits have not been protected [22]. In the process of urbanization in the city should be able to solve the employment problem caused by the increase of urban population, housing issues, transportation issues [23], education, health problems and infrastructure issues [28]. But the ability to accommodate a population of each city is limited, almost become saturated urban issues in residence, employment, housing, education, health care, pension, insurance, transportation,

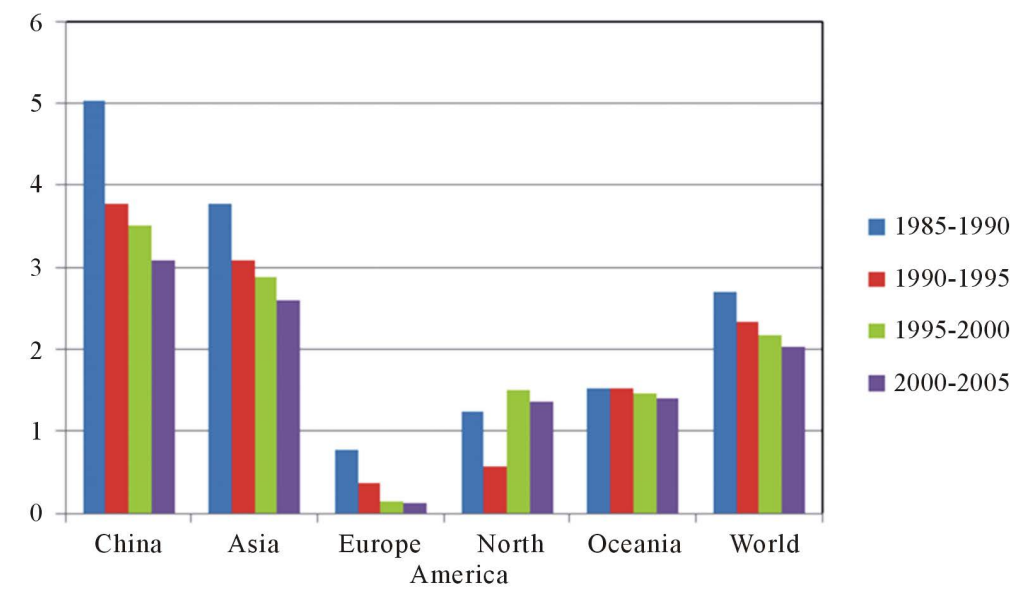

Figure 1. Urban population growth in China, comparing with continents and world (\%). 


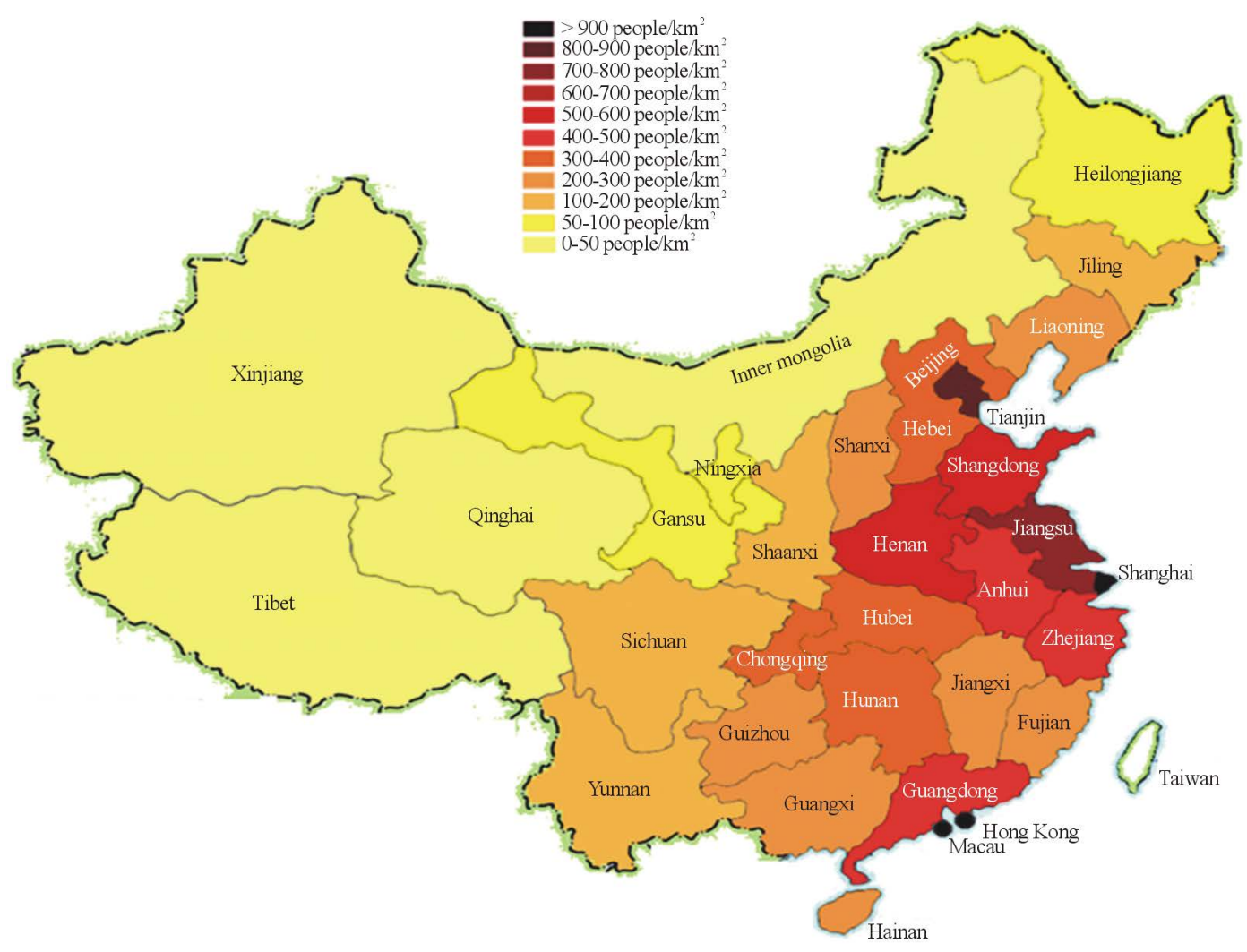

Figure 2. Population density of China.

production and management, and other prominent cultural life is particularly serious [24]. Urbanization in the presence of this series of questions, with the regulation of national policy, guidance, there will be room for improvement. However, the process of urbanization in energy consumption caused by environmental problems have been imminent, more serious environmental problem in the short term is irreversible process, of particular concern.

\subsection{Impact of Urbanization on Atmospheric Environment}

Urban air pollution is excessive expansion and rapid growth of the economy spawned a more prominent environmental issues [25] [26].

At present, China's urban ambient air quality is in heavier overall pollution levels [27]. The main pollutants are dust and sulfur dioxide [29]. Urban air pollution in winter and spring, heavier, summer, autumn light [30]; northern city of dust, dust pollution is heavy [38], heavy southern city of sulfur dioxide pollution, acid rain damage widening [28] [31]. Overall, the northern cities are more important than the southern cities [32].

Meanwhile, with the increasing number of cars in the city [33], environmental pollution caused by automobile exhaust has become increasingly serious [34] [35]; the atmosphere is facing the dual pressures of smoke pollution and car exhaust pollution [36]. In some cities, automobile exhaust emissions accounted for 35 percent of urban air pollution, some even more than $50 \%$, to prevent and reduce vehicle exhaust pollution has reached a critical state. Potential danger of photochemical smog caused by vehicle exhaust could erupt at any time [37]. At present, some Chinese large and medium cities in the hybrid vehicle exhaust soot and pollution.

In addition, urban heat island effect, urban average annual temperature increase, increase in temperature days, the city is also a fall in atmospheric visibility outstanding performance deterioration of urban atmospheric environment [38].

World Urban Air Quality Report 2011 released by the World Health Organization, China 31 capital cities, the air quality of the best sea, in 1082 the city of all surveyed ranked only 814, ranked No. 978 in the four municipalities Shanghai bit, the rest were in 1000 after the city overall air quality is poor [39]. 


\subsection{Impact of Urbanization on Water Resources}

Reduce the amount of water. Water pollution is also a city of over-expansion and rapid economic growth in the birth of the environmental problems [40] [41]. With the increase of urban population, industrial and agricultural water use and the amount of water needed for life is also increasing [42] [43]. China is not rich in water resources per capita, regional distribution is not uniform [44] [45], and a large inter-annual difference during the year is also unpredictable [46] [47]. The existing more than 600 cities in China, about 400 cities short of water, there are more than 100 cities severe water shortages, water shortages more than $60 \mathrm{million} / \mathrm{m}^{3}$ per year [48]. Urban water shortages caused by overload, the overall function decline [49] [50]. This is a limited resource, not only has not been effectively utilized, but often appears wasting water, water pollution phenomenon. More serious is irresponsible to indiscriminate discharge of industrial and domestic sewage, in recent years, the total national average wastewater enterprises in more than 100 million t per day. Among them, there are more than 80 percent of the wastewater did not get any treatment, or after a certain treatment, though, but still in line with the national emission standards. More than $90 \%$ of urban polluted waters, nearly $50 \%$ of key urban water do not meet drinking water standards. Indiscriminate discharge of waste water not only makes the original contamination of rivers and lakes of water, and gave a lot of creatures brought great harm, and therefore around the country more than two thirds of the city there will be a shortage of water. Consequences of urban water shortage in many cities is extensive use of groundwater, making lowering the water table, groundwater space destroyed, lose the ability to regenerate, the city always at risk of land subsidence.

\subsection{Impact of Urbanization on Waste Pollution}

Garbage polluting the environment is the more prominent urbanization problems [51]. With the urban population is growing, the amount of waste increases, according to experts, statistics 668 cities nationwide per capita production of $440 \mathrm{~kg}$ of solid domestic waste, accounting for more than a quarter of the world total. Now urban lifestyle has been "saving" to "abandon" change, waste production is growing, and at a rate of 8 to 10 percent annual growth, more than the world average growth rate (8.42\%). At the same time, waste disposal means generally lag behind, simple incineration, landfill, or even open dumps, causing huge economic losses, aggravated garbage siege phenomenon, and secondary pollution, long-term difficult to eliminate.

\subsection{Impact of Urbanization on Noise Problems}

Noise problem has been from the peaceful countryside to the bustling city of significant sign [52]. Environmental noise pollution in China is in addition to air pollution, water pollution, and the third largest environmental hazards. In the city, it has raised to the first major environmental hazards trend [53].

At present, nearly half of China's urban regional environmental noise pollution levels in the middle $33 \%$ of the urban part of light pollution [54]. Living among a wide range of noise, and was widening, traffic noise to disturb the largest living environment, construction noise nuisance is serious. The impact of the urban environment in a variety of noise sources, industrial noise accounted for $8 \%$ to $10 \%$ [55], about $5 \%$ of construction noise, traffic noise is about $30 \%$, or about 46 percent of social life noise.

\section{Conclusion}

Generally speaking, the analysis findings of this paper are in conjunction with the mainstream arguments of urbanization and urban development in China. However, the influences of urban compactness on studied environmental attributes are simply for being much less significant as had been expected. The explanation can be that general environmental quality of any city is usually a function of assorted social, economic, climatic, topographical, and institutional variables; the explanation power of density variables can be overwhelmed. Also, uncertainties with regards to multi-directional interaction of urban development variables, like urban form, population scope, density and their diversified effects on urban environmental performance bring about the complexness from the relationship.

\section{References}

[1] Ma, L.J. (2002) Urban Transformation in China, 1949-2000: A Review and Research Agenda. Environment and Plan- 
ning A, 34, 1545-1569.

[2] Zhang, G., Peng, S., Jing, L., Bai, J., Zhang, X., et al. (2012) Port Construction and Wetland Protection. China Forestry Publishing House, Beijing.

[3] Ma, C., Ju, M., Li, H., Zhang, X. and Cheng, C. (2011) Analysis of Change and Driving Force in Land Ecosystem Diversity in Tianjin. Acta Scientiarum Naturalium Universitatis Nankaiensis, 1, 13.

[4] Zhang, X., Ma, C., Gu, S., Ynag, J., Song, B., He, X., et al. (2009) Complexity of Ecosystem Dynamics. Acta Scientiarum Naturalium Universitatis Nankaiensis, 42, 99-104.

[5] Qiao, Y., Gu, S., Tang, Y., Du, M. and Gao, Y. (2008) Characteristics of Diffuse Radiation on the Qinghai-Tibetan Plateau. Acta Scientiarum Naturalium Universitatis Nankaiensis, 41, 69-78.

[6] Zhang, X., Ma, C., Chen, W. and Li, H. (2012) Ecological Water Requirement for Wetland Ecological Restoration in Tianjin Binhai New Area. South-to-North Water Diversion and Water Science \& Technology, 10, 63-66.

[7] Zhang, X., Cao, L. and Caldeira, K. (2013) Energy Switching Threshold for Climatic Benefits. AGU Fall Meeting Abstracts, 1, 1095.

[8] Ma, C., Zhang, G., Zhang, X., Li, H., Ju, M., Zhou, B., et al. (2012) Modes of Wetland Ecological Restoration in Tianjin Binhai New Area. South-to-North Water Diversion and Water Science \& Technology, 10, 30-33.

[9] Li, Y., Zhu, X., Sun, X. and Wang, F. (2010) Landscape Effects of Environmental Impact on Bay-Area Wetlands under Rapid Urban Expansion and Development Policy: A Case Study of Lianyungang, China. Landscape and Urban Planning, 94, 218-227. http://dx.doi.org/10.1016/j.landurbplan.2009.10.006

[10] Wang, Z., Zhan, S. and Zhang, X. (2012) Research on the Filling Problem of Liquefied Natural Gas Ships. Shanxi Architecture, 38, 273-274.

[11] Zhang, X.C., Chen, W.P., Ma, C. and Zhan, S.F. (2013) Modeling Particulate Matter Emissions during Mineral Loading Process under Weak Wind Simulation. Science of the Total Environment, 449, 168-173. http://dx.doi.org/10.1016/j.scitotenv.2013.01.050

[12] Zhang, X.C., Ma, C., Zhan, S.F. and Chen, W.P. (2011) Assessing Powder Emission Risk on Large Open-Air Yard of Coal Energy. Proceedings of the International Conference on Energy and Environmental Science, 11, 3047-3053.

[13] Zhang, X.C., Ma, C., Chen, W.P. and Gu, S. (2013) Global Utilization and Development of Wind Energy. Proceedings of the 2nd International Conference on Energy, Environment and Sustainable Development, 608, 584-587.

[14] Ma, C., Zhang, X.C., Zhang, G., Chen, W.P. and Gu, S. (2013) Global Utilization of Solar Energy and Development of Solar Cell Materials. Proceedings of the 2nd International Conference on Energy, Environment and Sustainable Development, 608, 151-154.

[15] Zhang, X.C., Ma, C., Zhan, S.F. and Lu, L.B. (2012) Planning and Construction of Eco-City: Theory Application and Case Study. Applied Mechanics and Materials, 174-177, 2408-2411. http://dx.doi.org/10.4028/www.scientific.net/amm.174-177.2408

[16] Zhang, X.C., Ma, C., Chen, W.P. and Zhan, S.F. (2013) Safety Design for Support Structure of Regional Wind System Engineering. Proceedings of the 2nd International Conference on Civil Engineering and Transportation, 256, 10291032.

[17] Zhang, X.C., Ma, C., Chen, W.P. and Zhan, S.F. (2012) Safety Management Standard Evaluation System for Port Based on AHP. Proceedings of the International Conference on Remote Sensing, Environment and Transportation Engineering, Nanjing, 1-3 June 2012, 2425-2428.

[18] Gao, Z., Gao, Y., Zheng, Z. and Zhang, X.C. (2009) A Comparative Study of Photosynthetic Characteristics of Caragana davazamcii between Plants of Different Ages in Huangfuchuan Basin of Ordos Plateau. Bulletin of Botanical Research, 2, 11.

[19] Ma, C., Zhang, G.Y., Zhang, X.C. and Li, Y.J. (2012) Application of Multiple Indicators in Environment Evaluation of Coastal Restoration Engineering: A Case Study in Bohai Bay in China. Applied Mechanics and Materials, 170, 22282232.

[20] Zhang, X.C., Chen, W.P., Ma, C. and Zhan, S.F. (2012) Modeling the Effect of Humidity on the Threshold Friction Velocity of Coal Particles. Atmospheric Environment, 56, 154-160. http://dx.doi.org/10.1016/j.atmosenv.2012.04.015

[21] Zhang, X.C., Myhrvold, N.P. and Caldeira, K. (2014) Evaluating the Climate Effects of Natural Gas vs. Coal Electricity Generation. Proceedings of the American Geophysical Union Fall Meeting, San Francisco, 15-19 December 2014, 625.

[22] Meng, W.Q., Ma, C., Ju, M.T., Li, H.Y. and Feng, H. (2008) Dynamic Calculation and Analysis of Eco-Footprints of Tianjin City in the Past Two Decades. Journal of Safety and Environment, 8, 67-71.

[23] Meng, W.Q., Li, H.Y., Ju, M.T., Ma, C., Shao, C.F. and Chang, H. (2008) An Overview of Restoration and Reconstruction of Damaged Ecosystem in Europe. Bulletin of Soil and Water Conservation, 28, 201-208. 
[24] Meng, W.Q., Li, H.Y., Ju, M.T., Wu, X. and Ma, C. (2008) Integrated Assessment of Urban Green Space Based on Citizen Requirement of Tianjin. Urban Environment \& Urban Ecology, 6.

[25] Chen, J., Zhan, S.F. and Zhang, X.C. (2009) Study on Construction Development and Theories of Green Port. Journal of Transport Information and Safety, 27, 198-202.

[26] Ma, C., Meng, W.Q. and Li, H.Y. (2006) Discussion on the Use of Ecological Concept. Sichuan Environment, 25, 5458.

[27] Zhang, X. and Caldeira, K. (2015) Timescales and Ratios of Climate Forcing Due to Thermal versus Carbon Dioxide Emissions from Fossil Fuels. Geophysical Research Letters, 42.

[28] Wang, J.F., Ma, L., Zhan, S.F., Zhang, X.C., Peng, S.T. and Ma, C. (2009) Effects of Moisture on Threshold Velocity of Coal Dust. Journal of Waterway and Harbour, 30, 209-212.

[29] Ma, C., Ju, M.-T., Zhang, X.C. and Li, H.Y. (2011) Energy Consumption and Carbon Emissions in a Coastal City in China. Procedia Environmental Sciences, 4, 1-9. http://dx.doi.org/10.1016/j.proenv.2011.03.001

[30] Ma, C., Zhang, X.C., Zhang, G., Ju, M.T., Zhou, B. and Li, X. (2012) Application of DPSIR Framework in Environmental Impact Assessment for Port Planning. China Environmental Science, 32, 107-111.

[31] Ma, C., Zhang, G., Zhang, X.C., Zhou, B. and Mao, T.Y. (2012) Simulation Modeling for Wetland Utilization and Protection Based on System Dynamic Model in a Coastal City, China. Procedia Environmental Sciences, 13, 202-213. http://dx.doi.org/10.1016/j.proenv.2012.01.019

[32] Ma, C., Zhang, G., Zhang, X.C., Zhao, Y. and Li, H. (2012) Application of Markov Model in Wetland Change Dynamics in Tianjin Coastal Area, China. Procedia Environmental Sciences, 13, 252-262. http://dx.doi.org/10.1016/j.proenv.2012.01.024

[33] Zhang, X., Myhrvold, N.P. and Caldeira, K. (2014) Key Factors for Assessing Climate Benefits of Natural Gas versus Coal Electricity Generation. Environmental Research Letters, 9, Article ID: 114022. http://dx.doi.org/10.1088/1748-9326/9/11/114022

[34] Zhan, S.F., Ma, C., Zhang, X.C., Chen, W. and He, Q. (2011) Evaluating Dust Emission Risk for Coal Energy Handling of Large Stacker on Wind Tunnel. Energy Procedia, 11, 3054-3059.

[35] Zhang, X.C., Myhrvold, N. and Caldeira, K. (2015) Assessing Climate Benefits of Natural Gas and Coal Electricity Generation. EGU General Assembly, Volume 17, EGU2015-13925.

[36] Zhang, X.C., Gu, S., Zhao, X., Cui, X., Zhao, L., Xu, S., et al. (2010) Radiation Partitioning and Its Relation to Environmental Factors above a Meadow Ecosystem on the Qinghai-Tibetan Plateau. Journal of Geophysical ResearchAtmospheres, 115.

[37] Zhang, X.C., Ma, C., Chen, W.P. and Zhan, S.F. (2012) Urban Atmospheric Environmental Health Risk Assessment on Landscape. Proceeding of the Conference on Urban Environmental Pollution 2012: Creating Healthy, Liveable Cities, Amsterdam, 17-20 June 2012.

[38] Zhang, X.C., Chen, W.P., Ma, C., Zhan, S.F. and Jiao, W.T. (2012) Regional Atmospheric Environment Risk Source Identification and Assessment. Environmental Science, 33, 4167-4172.

[39] Han, G., Zhan, S.F., Zhang, X.C. and Ma, C. (2009) Influence Factors and Mathematical Model of Coal Dust Particles Threshold Velocity. Journal of China Coal Society, 34, 1359-1363.

[40] Zhang, X.C., Ma, C., Zhan, S.F. and Chen, W.P. (2012) Evaluation and Simulation for Ecological Risk Based on Emergy Analysis and Pressure-State-Response Model in a Coastal City, China. Procedia Environmental Sciences, 13, 221-231. http://dx.doi.org/10.1016/j.proenv.2012.01.021

[41] Zhan, S.F., Zhang, X.C., Ma, C. and Chen, W.P. (2012) Dynamic Modelling for Ecological and Economic Sustainability in a Rapid Urbanizing Region. Procedia Environmental Sciences, 13, 242-251. http://dx.doi.org/10.1016/j.proenv.2012.01.023

[42] Ma, C., Li, H., Meng, W., Zhang, L. and Zhang, X.C. (2007) Use of Sustainable Landscape Design on Protection in Tianjin Coastal Wetlands. China Population, Resources and Environment, 17, 314-317.

[43] Zhang, X.C., Chen, W.P., Ma, C., Zhang, G. and Ju, M. (2012) Assessment Method for Regional Environmental Risk Based on Pressure-State-Response Model. China Environmental Science, 32, 84-87.

[44] Ma, C., Meng, W., Ju, M., Li, H., Zhang, X.C. and Hao, C. (2008) Dynamic Assessment of China’s Sustainable Development Possibility Based on the Eco-Environmental Footprint during the Period of 1997-2006. Journal of Safety and Environmental, 8, 75-80.

[45] Ma, C., Zhang, X.C., Zhang, L., Ju, M., Li, H. and Mo, X. (2010) Modified Sustainable Development Model of Tianjin Municipality Based on the Eco-Footprint Method. Journal of Safety and Environmental, 10, 127-131.

[46] Ma, C., Zhang, G., Zhang, X.C., Zhou, B. and Jiang, W. (2012) Water Resource Management for Wetland Restoration Engineering in Tianjin Coastal Area in China. Proceedings of the International Conference on Energy and Environ- 
mental Protection, 518, 4333-4336. http://dx.doi.org/10.4028/www.scientific.net/amr.518-523.4333

[47] Ma, C., Sun, Q., Zhou, Y., Li, H. and Zhang, X.C. (2007) TWINSPAN Classification and Selection of Alfalfa Cultivars. Prataculture \& Animal Husbandry, 24-27.

[48] Ma, C., Zhang, X.C., Chen, W.P., Zhang, G., Duan, H., Ju, M., et al. (2013) China’s Special Marine Protected Area Policy: Trade-Off between Economic Development and Marine Conservation. Ocean \& Coastal Management, 76, 111. http://dx.doi.org/10.1016/j.ocecoaman.2013.02.007

[49] Hu, Y., Gu, S., Jiang, S., Zhang, X.C., Li, J., Gao, Y.B. and Qiao, Y.L. (2010) Effect of Different Light Quality on Fruit Quality of “Darselect” Strawberry (Fragaria $\times$ ananassa Duch.). Journal of Sichuan Agricultural University, 28, 164-168.

[50] Ye, S.-L., Ma, C. and Ju, M.-T. (2009) Standardization Framework of Marine Sustainable Development Evaluation System. China Standardization, 36, 16-20.

[51] Zhan, S., Zhang, X.C. and Ma, C. (2009) Coal Classification Based on Environmental Protection and Burning Quality. Journal of China Coal Society, 34, 1535-1539.

[52] Zhang, G., Zhan, S. and Zhang, X.C. (2009) Theory and Technology for Aerosol Pollution Control in Port. China Communication Press, Beijing.

[53] Yeh, A.G.O. and Wu, F.L. (1996) The New Land Development Process and Urban Development in Chinese Cities. International Journal of Urban and Regional Research, 20, 330-353. http://dx.doi.org/10.1111/j.1468-2427.1996.tb00319.x

[54] Wang, Y.P., Wang, Y. and Wu, J. (2009) Urbanization and Informal Development in China: Urban Villages in Shenzhen. International Journal of Urban and Regional Research, 33, 957-973. http://dx.doi.org/10.1111/j.1468-2427.2009.00891.x

[55] Verburg, P.H., Schot, P.P., Dijst, M.J. and Veldkamp, A. (2004) Land Use Change Modelling: Current Practice and Research Priorities. GeoJournal, 61, 309-324. http://dx.doi.org/10.1007/s10708-004-4946-y 